\title{
Higher sustainability performance of intensive grazing versus zero-grazing dairy systems
}

\author{
Marijke Meul • Steven Van Passel • Dirk Fremaut • \\ Geert Haesaert
}

Accepted: 13 December 2011 / Published online: 12 January 2012

(C) INRA and Springer-Verlag, France 2011

\begin{abstract}
Although grazing of dairy cows is an integral part of dairy farming in many European countries, farmers today more often choose for zero-grazing systems, where cows are housed throughout the year. Some studies already compared grazing and zero-grazing systems for specific issues such as labor efficiency, environmental impact, or animal welfare. In our study, we perform a more integrated evaluation, considering relevant ecological, economic, and social aspects. This allows for a balanced and more complete comparison of the sustainability performance of the two production methods. We evaluated ten intensive grazing and ten zero-grazing specialized Flemish dairy farms on the use of nutrients and energy, productivity and profitability, labor input, and animal welfare. In addition, we put special effort in formulating useful management advice for farmers. Therefore, we combined a detailed analysis of the sustainability indicators with an intensive interaction and discussion with farmers and farm advisors. Results show that, on average, the zero-grazing farms performed significantly worse from an ecological and economic point of view. This fact is explained mainly due to a less efficient use of concentrates and byproducts. Social sustainability performance did not differ significantly between the two groups. As a result, the integrated sustainability performance was significantly lower for the zero-grazing group. This finding shows
\end{abstract}

\footnotetext{
M. Meul $(\bowtie) \cdot$ D. Fremaut $\cdot$ G. Haesaert

Department of Biosciences and Landscape Architecture, University College Ghent,

Valentin Vaerwyckweg 1,

BE-9000 Ghent, Belgium

e-mail: Marijke.meul@hogent.be

S. Van Passel

Centre for Environmental Sciences, Hasselt University, Agoralaan,

BE-3590 Diepenbeek, Belgium
}

that a further shift from intensive grazing to zero-grazing can move dairy farming in Flanders further away from sustainability. An important advice to improve the ecological and economic performance of zero-grazing farms is to optimize cows' rations to include more forages and optimize forage production and use. More detailed site- and case-specific management advice for farmers of both groups was provided during a discussion meeting. We consider this an essential additional step to any sustainability evaluation, since progress can only be made when monitoring results are translated into practical measures.

Keywords Sustainability performance $\cdot$ Management advice · Intensive grazing · Zero-grazing $\cdot$ Dairy systems . Flanders $\cdot$ MOTIFS

\section{Introduction}

Grazing of dairy cows is an integral part of dairy farming in many European countries. However, in the past decades, zero-grazing systems, where cows are housed throughout the year, have become more and more common (Haskell et al. 2006; Van Vuuren and Van Den Pol-Van Dasselaar 2006). Also in Flanders, there seems to be a trend towards restricted grazing of dairy cows. Two surveys among in total 787 Flemish dairy farmers in 2006-2007 showed that 4\% of the respondents already applied zero-grazing, while $37 \%$ of the farmers with grazing indicated their intention to reduce grazing in the future (Schellekens et al. 2008). Farmers choose to apply zero-grazing to be able to control diets, optimize grassland utilization, and achieve a higher milk production, higher labor efficiency, and lower nutrient losses. Other reasons to choose zero-grazing are scarcity of land in relation to herd size and the application of an automatic milking system (Coléno and Duru 1999; Parsons 
et al. 2004; Kristensen et al. 2005; Van Vuuren and Van Den Pol-Van Dasselaar 2006; Arsenault et al. 2009). Considering the expected trend towards more zero-grazing in the future, it is important to analyze whether this will have a positive or negative effect on the sustainability of dairy farming in Flanders and other comparable European regions.

Generally, zero-grazing farms are more intensive farms that handle more cows than grazing systems and supply highly controlled diets of concentrates and stored forages such as grass or maize silage. They are characterized by high milk yields and increased inputs of nutrients and energy (Kristensen et al. 2005; Arsenault et al. 2009). Due to their intensification and their potential to control diets, facilitate work organization, and avoid grazing-related organizational difficulties, zero-grazing systems are expected to make more efficient use of resources than more traditional grazing systems (Coléno and Duru 1999; Haskell et al. 2006; Arsenault et al. 2009). Increased milk production can lead to significant savings in production costs and increase energy use efficiency (Zimmermann 2008). Zero-grazing systems can reduce nitrate losses from grasslands, because urine and dung patches are associated with high nitrogen concentrations and are "hot spots" for nitrate leaching (Rotz et al. 2005). On the other hand, ammonia volatilization from stables, manure storage, and field application in zero-grazing dairy systems is usually higher than volatile ammonia loss from grazing livestock (Whitehead 1995). Also, the increased input of concentrates, nutrients, and energy associated with intensification leads to increased emissions with a negative impact on global warming potential, eutrophication, and acidification (Haas et al. 2001; Zimmermann 2008; Arsenault et al. 2009). An increased length of the housing period can decrease welfare of dairy cows, since they are subject to a higher incidence of lameness, leg injuries, and other maladies, which in turn negatively affect milk production causing potential significant economic losses for farmers (Haskell et al. 2006; Olmos et al. 2009; von Keyserlingk et al. 2009).

Grazing systems are much more diversified, since they can range from extensive systems with low stocking densities, long grazing periods, and low use of concentrates to intensive systems with high stocking densities, a more restricted grazing schedule and the supplementation of concentrates and stored forages to maximize milk production. Grazing has been found to be associated with lower production costs (Soriano et al. 2001), lower energy and mineral fertilizer use, and lower use of concentrates, since well-maintained pasture is a highly nutritious feed source (Arsenault et al. 2009). Generally, grazing of dairy cows is considered to increase biodiversity of grasslands since it creates favorable conditions for the formation of habitat structure preferred by many birds, small mammals, and invertebrates (Metera et al. 2010). Due to its contribution to animal welfare, biodiversity, and the general aesthetic importance of pastures, grazing of cows has become an important issue for consumers (Spörndly and Wredle 2004; Conner and Campbell-Arvai 2009).

These findings show that both production methods have specific strengths and weaknesses. To perform a balanced comparison of the grazing versus zero-grazing dairy production method, a systems-based approach should be applied to weigh their various advantages and disadvantages (Van Vuuren and Van Den Pol-Van Dasselaar 2006; Arsenault et al. 2009). Therefore, the aim of our study is to evaluate the integrated sustainability performance of grazing versus zerograzing dairy systems in Flanders, considering relevant economic, ecological, and social sustainability aspects. In addition, we put special effort in formulating site- and casespecific management advice for farmers. This is especially important in our case, since farmers can often shift between zero-grazing and grazing. Moreover, each farmer can have an effect on most sustainability aspects through the management strategy and can thereby reduce or remove the negative effects of a certain production method (Van Vuuren and Van Den Pol-Van Dasselaar 2006; Hernandez-Mendo et al. 2007).

\section{Materials and methods}

\subsection{The case-study farms}

We evaluated 20 specialized Flemish dairy farms, ten with grazing and ten with permanent housing of dairy cows, associated with the same private farm accountancy and consultancy organization. The zero-grazing farms were characterized by a significantly larger herd size, higher total milk production, and higher use of concentrates and byproducts per cow, while the available grassland area per cow was significantly lower compared with the grazing farms (Table 1). Milk yield per cow was similar in both groups. All dairy cows were Holstein-Friesian breed housed in cubicle stables, except for one grazing farm with a tie-stall barn. Besides fresh grass during the grazing period for the grazing cows, the rations included a mixture of conserved forages such as grass and maize silage, byproducts such as beet pulp and brewers' grains, and concentrates. Within the grazing group, a large variability in grazing period occurred and dairy cows were also housed for a longer time per year. Compared with average farm characteristics of a representative group of Flemish dairy farms (Platteau et al. 2010), all farms in our case-study can be considered large, intensive farms, since also the grazing farms are characterized by high milk productions, high milk yields per cow, and high stocking densities.

During data acquisition, farmers were asked why they chose a specific production method. Farmers who applied zero-grazing mentioned higher labor efficiency and better 
Table 1 Mean value and range of farm characteristics of the grazing and zero-grazing casestudy farms, based on farm accountancy data for 2009

*Indicates significant differences between the means $(P<0.05$, ANOVA)

${ }^{\mathrm{a} C}$ Comprises total grassland area and area used for forage crop production, mainly maize

${ }^{\mathrm{b}}$ The use of different concentrates and byproducts was recalculated to a universal $88 \%$ dry matter content

Unit

Zero-grazing farms

Grazing farms

Farm intensity and scale

Degree of specialization

Herd size

Share of heifers

Stocking rate

Total milk production

Milk yield per cow

Milk yield per hectare

Land use

Forage area $^{\mathrm{a}}$

Forage area per cow

Grassland area per cow

Feeding strategy

Grazing period for dairy cows

Use of concentrates

and byproducts ${ }^{\mathrm{b}}$
Percent of value added

Number of dairy cows

Percent of dairy cows

Cows per ha forage area

Ton milk

Kilograms milk per cow

Tons milk per hectare forage area

Hectare

Hectare per cow

Hectare per cow

Hours per year

Kilogram per cow per year
$91(74-100)$

99 (52-127)

81 (59-115)

$2.12(1.52-3.11)$

848 (403-1141)

8603 (7873-9542)

$17.8(13.7-25.5)$

$51(18-83)$

$0.50(0.32-0.66)$

$0.21(0.06-0.34)$

$15(0-150)$

2690 (1768-3613)
$94(82-100)$

$74(43-100)^{*}$

83 (59-99)

$1.87(1.51-2.55)$

$619(397-870) *$

8697 (6551-10078)

$15.8(12.6-23.5)$

41 (17-57)

$0.55(0.39-0.66)$

$0.29(0.21-0.42)^{*}$

1463 (340-3366)

2087 (1431-2796)* feed supply, while farmers who applied grazing mentioned better animal welfare and positive impact on the farm's image towards consumers as the most important reasons.

\subsection{Sustainability themes and indicators}

We used a selection of sustainability indicators from MOTIFS (Monitoring Tool for Integrated Farm Sustainability; Meul et al. 2008), a tool for Flemish dairy farmers to monitor farm progress towards integrated sustainability, i.e., taking into account economic, ecological, and social aspects. A detailed description of the development, validation, and application of MOTIFS is provided by Meul et al. (2008, 2009); De Mey et al. (2011), and Van Passel and Meul (2012). Ecological performance of the farms was evaluated by their energy and nutrient use, economic performance by their productivity and profitability, and social performance was measured through labor efficiency and animal welfare. These specific sustainability themes were chosen because we expected them to be most affected by the type of production method, based on the results from other studies as described in the section 1 and because they can be influenced directly by farm management. Moreover, for the selected indicators, we were confident that reliable and adequate data could be gathered, since they were already extensively validated and applied in previous applications (Meul et al. 2009; De Mey et al. 2011). All inputs and outputs related to a potential secondary farm activity, e.g., arable or pig production, were excluded from the analysis, so comparisons between the farms exclusively related to dairy activities.

Nutrient use was evaluated using four indicators: nitrogen (N) surplus, phosphorous (P) surplus, N-use efficiency, and Puse efficiency. $\mathrm{N}$ surplus is total $\mathrm{N}$ input in imported animals, concentrates, forages, byproducts, mineral fertilizer and manure minus total $\mathrm{N}$ output in exported milk, animals, manure, and forages. All inputs and outputs were based on farm accountancy data and are expressed in kilograms $\mathrm{N}$ per hectare of forage area. N-use efficiency is the ratio between amount of produced milk and $\mathrm{N}$ surplus. The calculation of $\mathrm{P}$ surplus and P-use efficiency was the same as those for N. A detailed description of the indicators is provided by Nevens et al. (2006). Annual energy use was estimated by the energy use efficiency, which is the ratio of the amount of produced milk to the total energy input, comprising direct and indirect energy inputs. Direct energy is used on farm for agricultural activities, and it comprises mainly diesel fuel and electricity, while energy used to produce farm inputs such as mineral fertilizers, seeds, pesticides, concentrates, forages, and machines is indirect energy. All necessary data were extracted from the farm accountancies. A detailed description of this indicator is provided by Meul et al. (2007).

Productivity was calculated using farm accountancy data and comprises land, labor, and capital productivity (Meul et al. 2008). Its calculation is based on the value added which are the total revenues from dairy minus the total variable costs related to dairy production. Value added was divided by the forage area to calculate land productivity, by the number of man-working units (MWU) dedicated to dairy production to calculate labor productivity and by the total farm capital dedicated to dairy production to calculate capital productivity. Profitability was estimated through labor profitability which is the farm labor income per unit of labor and by the return on assets, which is the farm profit per unit of farm capital. Labor income was calculated by subtracting the fixed costs for land and capital invested in dairy production from the produced 
value added. Farm profit was calculated by subtracting a fictive cost for the labor used in dairy production from the labor income. Hence, the return on assets represents the rate of return that is received from the amount of capital invested in the farm's dairy activities.

Labor efficiency was not included as a social sustainability theme in MOTIFS as described by Meul et al. (2008). However, during previous applications of the tool, farmers considered labor efficiency as an interesting and relevant social sustainability theme. Zimmermann (2008) also considers labor an important social aspect when comparing the sustainability of different dairy-cow feeding methods. Since the farmers in our case-study indicated higher labor efficiency as a main reason to choose for zero-grazing, we found it justified and relevant to include this theme. Based on the methodology used in studies concerning labor efficiency on dairy farms in The Netherlands (Roelofs et al. 2005), we estimated labor demand during 4 weeks, using a time registration table in which every farmer recorded exactly how much time was spent on predefined activities: milking, livestock care, feeding, maintenance, grassland production, forage crops production, administration, contract work, and other activities. Labor recording began the first week of March 2010. This was chosen as a reference week during the winter, when the dairy cows are housed in both groups. The following recording weeks were spread evenly through the grazing season, i.e., the last week of May and the first week of July and August 2010. Labor efficiency was calculated by dividing the total annual milk production by the estimated annual labor input, which is the mean weekly labor input of the four registration weeks, multiplied by 52 . To evaluate animal welfare, four MOTIFS-indicators were used: (1) bodycondition score, i.e., the percentage of very thin cows; (2) the share of dirty cows, based on the dirtiness of udders, flanks, and legs; (3) the share of cows with lesions on hocks, neck, and spine; and (4) locomotion score, which is the share of lame cows (Sobry et al. 2005). Dairy cows were scored in February 2010, during the housing period, and in October 2010 , just after the grazing season. For each farm, at least half of the total number of lactating dairy cows were scored, with a minimum of 50 animals. Each observation was performed by the same two observers.

\subsection{Evaluation of integrated sustainability performance}

We performed a visual and numerical integration of the applied sustainability indicators. Therefore, indicator values were rescaled into scores between 0 , indicating a worst-case situation and 100, indicating assumed maximum sustainability. Ideally, an absolute sustainability evaluation would be performed using absolute thresholds, norms, or target values to rescale the indicators. However, these are often difficult to identify due to lack of scientific arguments (Bockstaller et al.
2008). Therefore, in our study, we performed a relative comparison of the sustainability performance of the grazing and zero-grazing systems, using relative benchmark values. For each indicator, the tenth and 90th percentiles - the two best performing and two lowest performing farms - were used as respective minimum and maximum benchmark values. Intermediate indicator values were transferred into linearly intermediate scores. This relative scaling method was highly appreciated during previous applications of MOTIFS since it results in a dynamic and motivating tool for farmers, setting realistic goals. We considered this approach justified for our case-study since we perform a relative comparison of the sustainability performance of two production methods. We integrated the indicator scores visually in a radar graph and numerically by calculating weighted mean scores for ecological, economic, and social performance. As described by Meul et al. (2008) and Zimmermann (2008), indicators were weighed according to the assumption that all selected sustainability themes are equally important. This rule takes into account the equality of the economic, ecological, and social pillars. Within a specific theme, we considered all indicators as equally important and consequently assigned them an equal weight. Mean indicator values and scores of the two groups were compared using ANOVA.

\subsection{Formulating management advice}

Figure 1 summarizes the different steps applied during the evaluation of the sustainability performance and the formulation of management advice. The translation of sustainability monitoring results into practical measures is an integral part of the application of MOTIFS (Meul et al. 2009; De Mey et al. 2011). Starting from the calculated indicator values, we identified a set of most influential management indicators. Therefore, we first used multiple regression to identify the most influential factors, i.e., independent variables, for each indicator value, i.e., dependent variable. For example, for the $\mathrm{N}$-surplus indicator, the $\mathrm{N}$ inputs and outputs are the independent variables. We selected the independent variables associated with a $P$ value $<0.05$ as the most influential factors for the indicator. Next, through correlation analysis, the selected factors were related to specific farm management indicators such as farm intensity or concentrate use. This analysis was performed using data from all 20 dairy farms, and the resulting farm management indicators were used to formulate general management advice. More detailed site- and case specific advice was delivered to the 20 participating farmers through an extended feedback report including a detailed representation of the MOTIFS results and comparison of the farm results to the means of the grazing and zero-grazing group. Afterwards, all farmers were invited to participate in a discussion group with the researchers, farm advisors, and an invited expert. During previous applications of MOTIFS, the organization 


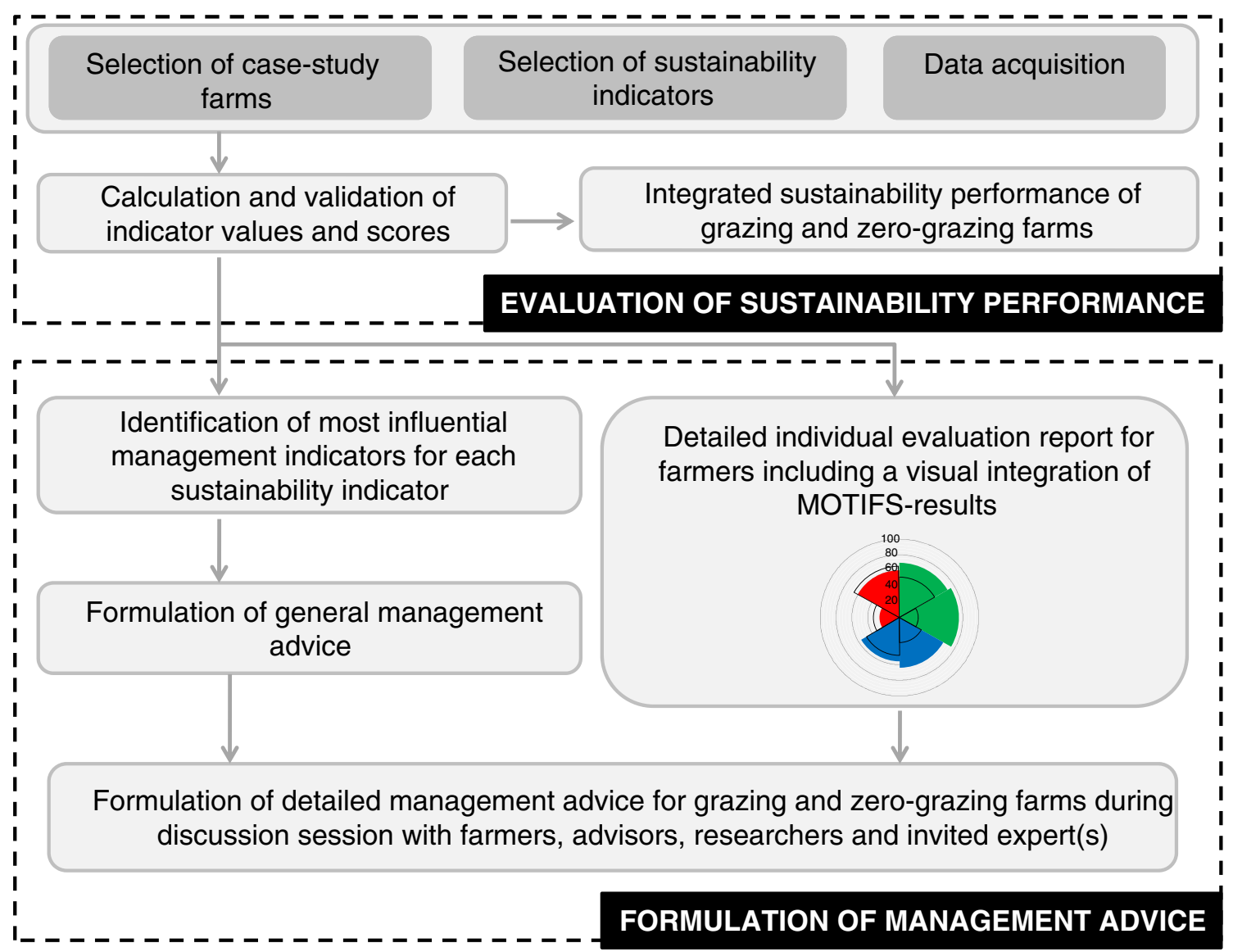

Fig. 1 Applied methodology to evaluate sustainability performance and formulate management advice

of discussion sessions among farmers was found very useful to strengthen the management support, since it allows farmers to mutually compare results and exchange knowledge.

Stakeholder participation played an important role in our study: Case-study farms were selected based on discussions between researchers and farm advisors. Farmers and farm advisors were involved in data acquisition, and farm advisors were consulted during identification of the most influential management indicators; they also facilitated the discussion session.

\section{Results and discussion}

3.1 Sustainability performance of grazing versus zero-grazing farms

There was a large within-group variability in indicator values and scores (Table 2). However, despite this large variability, the grazing farms scored systematically higher for all ecological and economic sustainability indicators. The mean values and scores for energy productivity, labor profitability, and land productivity were significantly higher compared with the zero-grazing group. The zero-grazing farms on the other hand scored higher for labor efficiency, while surprisingly animal welfare was not significantly different between the two groups. During the housing period, mean animal welfare scores were quite similar, only the mean score for dirtiness was substantially higher for the zero-grazing farms. After the grazing period, the grazing farms had a higher mean score for most indicators except for dirtiness.

A visual integration of the mean weighted indicator scores for both production methods is provided in Fig. 2. Summarized, zero-grazing performed worse from an ecological and economic point of view, while social performance was not significantly different between the two production methods. The overall integrated sustainability score was significantly higher for grazing (Table 2), which is in line with the findings of Zimmermann (2008), who concluded that for the three sustainability dimensions, performance can be enhanced by a higher proportion of grazing. On the other hand, Arsenault et al. (2009) found no significant differences in environmental impact between intensive grazing and zero-grazing dairy systems.

The selected economic, ecological, and social indicators allowed us to perform a balanced, three-pillar evaluation of the sustainability performance of grazing versus zero-grazing farms, using reliable and adequate data. It should be noted, 
Table 2 Mean value and range of the applied sustainability indicators at the grazing and zero-grazing dairy farms, the maximum (Bmax), and minimum (Bmin) benchmark values and the related sustainability scores

\begin{tabular}{|c|c|c|c|c|c|c|c|c|}
\hline \multirow{2}{*}{$\begin{array}{l}\text { Sustainability } \\
\text { theme }\end{array}$} & \multirow[t]{2}{*}{ Indicator } & \multirow[t]{2}{*}{ Unit } & \multicolumn{2}{|l|}{ Indicator values } & \multicolumn{2}{|c|}{ Benchmark values } & \multicolumn{2}{|c|}{ Indicator scores } \\
\hline & & & Zero-grazing farms & Grazing farms & Bmax & Bmin & Zero-grazing & Grazing farms \\
\hline Energy & $\begin{array}{l}\text { Energy use } \\
\text { efficiency }\end{array}$ & $\begin{array}{l}\text { Liter milk per } \\
100 \mathrm{MJ}\end{array}$ & $25.12(19.86-35.51)$ & $30.3(23.16-39.24)^{* *}$ & 37.65 & 21.24 & $24(0-87)$ & $54(12-100)^{* *}$ \\
\hline \multirow[t]{4}{*}{ Nutrients } & $\begin{array}{l}\text { Nitrogen }(\mathrm{N}) \\
\text { surplus }\end{array}$ & kg N per ha & $213(141-328)$ & 185 (121-269) & 136 & 269 & $47(0-97)$ & $63(0-100)$ \\
\hline & $\mathrm{N}$ use efficiency & $\begin{array}{l}\text { Liter milk per } \\
\text { kg N surplus }\end{array}$ & $87(61-189)$ & $90(50-136)$ & 136 & 55 & $33(8-100)$ & $44(0-100)$ \\
\hline & $\begin{array}{l}\text { Phosphorous } \\
\text { (P) surplus }\end{array}$ & kg P per ha & $10.5(-3.4-28.7)$ & $6.9(-2.8-16.8)$ & 0 & 23.6 & $56(0-100)$ & $70(30-100)$ \\
\hline & $P$ use efficiency & $\begin{array}{l}\text { Liter milk per } \\
\text { kg P surplus }\end{array}$ & $1612(698-3018)$ & $2334(734-4525)$ & 4525 & 734 & $39(0-100)$ & $48(0-100)$ \\
\hline \multirow[t]{3}{*}{ Productivity } & Labor productivity & Euro per MWU & $30100(9632-47322)$ & $33823(21270-56179)$ & 47322 & 16861 & $46(0-100)$ & $53(14-100)$ \\
\hline & Land productivity & Euro per ha & 1808 (1241-2267) & $2361(1022-3789)^{*}$ & 3073 & 1241 & $31(0-56)$ & $58(0-100)^{* *}$ \\
\hline & $\begin{array}{l}\text { Capital } \\
\text { productivity }\end{array}$ & Euro per Euro & $0.22(0.14-0.45)$ & $0.27(0.15-0.56)$ & 0.45 & 0.15 & $24(0-100)$ & $36(0-100)$ \\
\hline \multirow[t]{2}{*}{ Profitability } & Labor profitability & Euro per MWU & $13251(5476-23226)$ & $21280(7805-36002)^{* *}$ & 5719 & 29297 & $32(0-74)$ & $63(9-100)^{* *}$ \\
\hline & Return on assets & Euro per Euro & $-0.05(-0.19-0.04)$ & $-0.02(-0.17-0.05)$ & 0.04 & -0.17 & $60(0-100)$ & $73(0-100)$ \\
\hline Labor efficiency & Labor efficiency & $\begin{array}{l}\text { Liter milk per } \\
\text { working hour }\end{array}$ & $155(105-234)$ & $133(99-211)$ & 230 & 100 & $42(4-100)$ & $26(0-85)$ \\
\hline $\begin{array}{l}\text { Animal } \\
\text { welfare during }\end{array}$ & $\begin{array}{l}\text { Body condition } \\
\text { score }(\mathrm{H})\end{array}$ & $\%$ very thin cows & $1.12(0-6.56)$ & $0.94(0-4.76)$ & 0 & 4.76 & $80(0-100)$ & $80(0-100)$ \\
\hline \multirow[t]{3}{*}{ Housing period } & Dirtiness $(\mathrm{H})$ & $\%$ dirty cows & $27.29(4.35-57.81)$ & $39.8(23.53-76.56)$ & 6.25 & 69.44 & $66(18-100)$ & $48(0-73)$ \\
\hline & Skin lesions $(\mathrm{H})$ & $\%$ cows with lesions & $58.98(34.85-89.06)$ & $58.87(15.63-87.30)$ & 25 & 87.3 & $46(0-84)$ & $44(0-100)$ \\
\hline & $\begin{array}{l}\text { Locomotion } \\
\text { score }(\mathrm{H})\end{array}$ & $\%$ lame cows & $18.39(9.38-29.69)$ & $18.63(7.81-36.51)$ & 8.16 & 29.69 & $52(0-94)$ & $54(0-100)$ \\
\hline $\begin{array}{l}\text { Animal } \\
\text { welfare after }\end{array}$ & $\begin{array}{l}\text { Body condition } \\
\text { score }(\mathrm{G})\end{array}$ & $\%$ very thin cows & $0.82(0-1.96)$ & $0(0-0)$ & 0 & 1.59 & $51(0-100)$ & $100(100-100)$ \\
\hline \multirow[t]{3}{*}{ Grazing period } & Dirtiness $(\mathrm{G})$ & $\%$ dirty cows & $11.12(1.59-26.98)$ & $14.82(3.13-34.04)$ & 3.13 & 26.98 & $66(0-100)$ & $54(0-100)$ \\
\hline & Skin lesions $(G)$ & $\%$ cows with lesions & $32.76(14.06-64.29)$ & $29.92(7.50-68.25)$ & 8.7 & 64.29 & $57(0-90)$ & $62(0-100)$ \\
\hline & $\begin{array}{l}\text { Locomotion } \\
\text { score }(\mathrm{G})\end{array}$ & $\%$ lame cows & $7.03(0-15.38)$ & $4.51(0-10.94)$ & 0 & 11.76 & $43(0-100)$ & $62(7-100)$ \\
\hline \multicolumn{3}{|c|}{ Weighted average ecological score } & & & & & $28(5-49)$ & $43(15-56)^{* *}$ \\
\hline \multicolumn{3}{|c|}{ Weighted average economic score } & & & & & $40(1-77)$ & $59(20-88)^{*}$ \\
\hline \multicolumn{3}{|c|}{ Weighted average social score } & & & & & $50(21-90)$ & $44(24-78)$ \\
\hline \multicolumn{3}{|c|}{ Integrated overall sustainability score } & & & & & $39(17-63)$ & $49(33-59)^{*}$ \\
\hline
\end{tabular}

*indicates significant differences between the means $(* * P<0.05 ; * P<0.1$; ANOVA)

$M W U$ man-working unit (1 MWU equals $1,800 \mathrm{~h}$ of labor input), $H$ housing period, $G$ grazing period

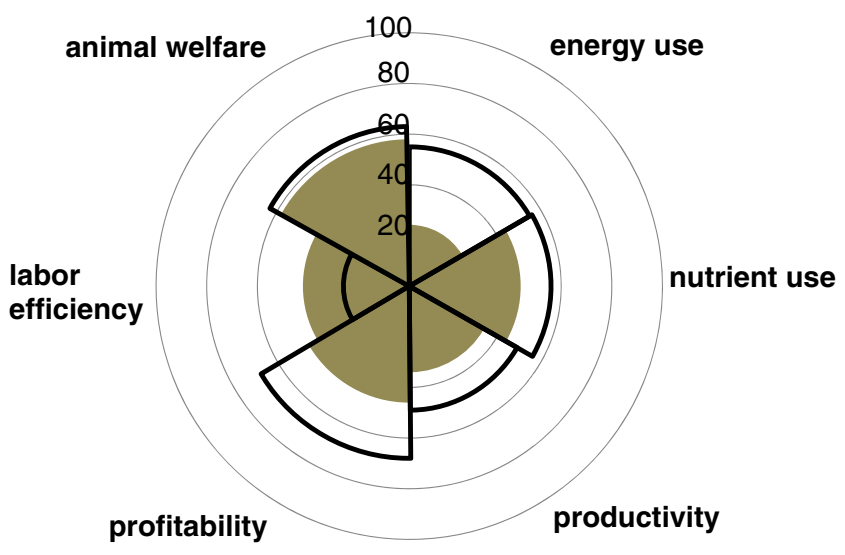

Fig. 2 Visual integration of mean sustainability indicator scores of zero-grazing (grey fill) and grazing (black bold line) dairy farms however, that off-farm externalities such as global warming, acidification, and eutrophication potential were not considered, and a more extended life cycle analysis should be applied to fully incorporate these environmental impacts. Also, other sustainability aspects such as water use, biodiversity, or landscape quality were not considered in our analysis and including these would definitely broaden the evaluation. Therefore, it should be kept in mind that the lower sustainability performance of zero-grazing in our study is the result of the evaluation of a limited number of sustainability aspects measured at farm level and adding other aspects can possibly affect this conclusion. Moreover, due to the use of relative benchmarks for the sustainability indicators, the higher sustainability performance of the grazing farms does not necessarily imply that this production method reaches absolute sustainability, and it could well be that the best performing farms from our dataset are still not sustainable. 


\subsection{Formulating management advice}

Regression analysis showed that energy productivity was highly determined by the input of energy from concentrates and byproducts and input from diesel $\left(R^{2}=0.92\right)$. N surplus, $\mathrm{P}$ surplus, and $\mathrm{N}$ use efficiency were highly determined by the input of nutrients from mineral fertilizers, concentrates and byproducts, forages, and exported nutrients in milk and manure $\left(R^{2}=0.93,0.82\right.$, and 0.96 , respectively). Energy and $\mathrm{N}$ input from concentrates and byproducts were significantly higher at the zero-grazing farms (Table 3), and these factors were strongly related to respectively the use of concentrates and byproducts per cow $\left(R^{2}=0.79\right)$ and per hectare $\left(R^{2}=0.65\right)$. Hence, the significantly higher use of concentrates and byproducts at the zero-grazing farms (Table 1) did not lead to a similar increase in milk yields at these farms and resulted in an overall higher nutrient surplus and lower nutrient and energy use efficiency.

The most influential factors of the farms' productivity indicators were the income from sold milk, costs for concentrates and byproducts, forage production, maintenance, fertility and other variable costs, and the number MWU (for labor productivity; $R^{2}=0.91$ ), the forage area (for land productivity; $R^{2}=0.88$ ), and invested capital (for capital productivity; $R^{2}=$ 0.88 ). The same variable costs also determine the profitability indicators, together with the income from sold milk, fixed costs, and the number of MWU (for labor profitability; $R^{2}=$ 0.88 ) and total capital (for return on assets; $R^{2}=0.59$ ). The significantly higher costs for concentrates and byproducts at the zero-grazing farms (Table 3) were logically strongly correlated with the higher use of concentrates and byproducts per cow $\left(R^{2}=0.74\right)$, which therefore not only affected the ecological performance, but also resulted in a lower economic performance of this group.

The major environmental and economic impact of concentrate use in dairy production has been shown in other studies (e.g., Nevens et al. 2006; Meul et al. 2007; Thomassen et al. 2008). Therefore, decreasing input of concentrates by including a higher proportion of forages in the feed ration can improve environmental performance of the zero-grazing farms (Zimmermann 2008; Arsenault et al. 2009) and reduce their production costs. Figure 3 shows the large variability in the use of concentrates and byproducts between farms with a comparable available forage area per cow. Management of the farms above the regression line could be optimized, since they use a lot of concentrates and byproducts compared with other farms with the same available forage area per cow and applying the same production method. Including a higher proportion of forages in the diet can be realized through optimization of grassland management and forage production and use, and by avoiding losses during grazing, harvesting, preservation, and feeding. This optimization potential was discussed in detail during the discussion meeting with the farmers, farm advisors, and an invited expert in ration optimization and forage production. The farmers from the zero-grazing group with comparably high use of concentrates and byproducts declared that they preferred labor convenience over optimizing forage production and ration optimization and therefore did not fully attend the potential forage yield and use at their farms. Most grazing farmers were able to better consolidate the available forage products because they paid more attention to ration optimization and grassland management. It was mentioned, however, that a good consolidation of the available forage area requires high management skills on the part of the farmers. During the discussion meeting, detailed and technical case-specific advice concerning grassland management and forage production and use was provided by the invited expert and specific questions of the farmers were answered.

The income from sold milk was correlated with the milkfat and protein content $\left(R^{2}=0.52\right)$. Therefore, the significantly lower income from sold milk at the zero-grazing farms (Table 3) could largely be explained by the lower mean milk-fat and protein content of $4.10 \%$ fat and $3.47 \%$ protein compared with $4.37 \%$ fat and $3.52 \%$ protein for the grazing group. Since milk composition is highly responsive to cow diets (Jenkins and McGuire 2006), the different feeding strategies could have generated the different milkfat and protein contents observed. However, this hypothesis could not be verified from the farm accountancy data or the discussion meeting. "Other variable costs" include those for tap water and bedding materials, which were significantly higher for zero-grazing farms due to the full-time housing of cows. Since these costs are small, management strategies aiming to decrease them, e.g., increasing water use efficiency in the stables, are not likely to increase the overall economic performance of the zero-grazing farms.

Labor efficiency was determined by the efficiency of milking, livestock care, feeding, maintenance, and grassland and forage crops production $\left(R^{2}=0.99\right)$. The time per unit of milk production spent on grassland and forages was significantly lower on the zero-grazing farms, which indicates that stopping grazing would increase labor efficiency of forage production (Table 3). A higher labor efficiency was mentioned by the farmers as a major reason to shift from grazing to zerograzing, and our results confirm this expectation. However, per unit of milk production, most time was spent on milking (Table 3), and this factor was strongly related to farm scale, expressed as total milk production $\left(R^{2}=0.60\right)$. This makes sense, since large farms generally have larger milking installations, allowing them to milk more efficiently. Since total milk production was higher at the zero-grazing farms (Table 1), the higher labor efficiency of this group is therefore mainly explained by the larger farm scale and only to a lesser extent by the applied production method. Moreover, it should be noted that this higher labor efficiency could not be validated 
Table 3 Mean values of the most influential factors explaining sustainability indicator values of grazing and zero-grazing farms
$* P<0.05 ; * * P<0.1$ indicates significant differences between the means; ANOVA

$M W U$ man-working unit, $1 \mathrm{MWU}$ equals $1,800 \mathrm{~h}$ of labor input

\begin{tabular}{|c|c|c|c|}
\hline \multirow[t]{2}{*}{ Factor } & \multirow[t]{2}{*}{ Unit } & \multicolumn{2}{|c|}{ Mean factor values } \\
\hline & & Zero-grazing & Grazing \\
\hline Energy use diesel & MJ per 1001 milk & 71.5 & 58.8 \\
\hline Energy use concentrates and byproducts & MJ per 1001 milk & 234.9 & $170.7^{*}$ \\
\hline $\mathrm{N}$ input mineral fertilizers & kg N per ha & 131.7 & 140.6 \\
\hline $\mathrm{N}$ input concentrates and byproducts & $\mathrm{kg} \mathrm{N}$ per ha & 215.8 & $155.7^{* *}$ \\
\hline $\mathrm{N}$ input forages & kg N per ha & 13.6 & 12.3 \\
\hline $\mathrm{N}$ export milk & kg N per ha & 100.4 & 89.8 \\
\hline $\mathrm{N}$ export manure & kg N per ha & 41.1 & 30.1 \\
\hline $\mathrm{P}$ input mineral fertilizers & kg P per ha & 30.7 & 24.6 \\
\hline $\mathrm{P}$ input concentrates and byproducts & kg P per ha & 2.2 & 2.3 \\
\hline$P$ input forages & kg P per ha & 2.1 & 2.0 \\
\hline P export milk & kg P per ha & 15.9 & 14.8 \\
\hline $\mathrm{P}$ export manure & kg P per ha & 8.0 & 4.5 \\
\hline \multicolumn{4}{|l|}{ Variable costs } \\
\hline Concentrates and byproducts & $€$ per 1001 milk & 8.7 & $7.1^{*}$ \\
\hline Forage production & $€$ per 1001 milk & 4.7 & 5.4 \\
\hline Fertility & $€$ per 1001 milk & 0.4 & 0.5 \\
\hline Maintenance & $€$ per 1001 milk & 0.9 & 0.8 \\
\hline Other variable costs & $€$ per 1001 milk & 1.4 & $0.8^{* *}$ \\
\hline Income from sold milk & $€$ per 1001 milk & 26.6 & $28.4^{*}$ \\
\hline Number of MWU & MWU per million 1 milk & 4.0 & 4.6 \\
\hline Forage area & ha per million 1 milk & 59.7 & 66.9 \\
\hline Fixed costs & $€$ per 1001 milk & 5.8 & 5.5 \\
\hline Invested capital & $€$ per 1001 milk & 52.4 & 63.0 \\
\hline Total capital & $€$ per 1001 milk & 91.7 & 114.5 \\
\hline \multicolumn{4}{|l|}{ Invested labor } \\
\hline Milking activities & Minutes per 1001 milk & 17.6 & 20.9 \\
\hline Livestock care & Minutes per 1001 milk & 11.4 & 10.5 \\
\hline Feeding activities & Minutes per 1001 milk & 4.8 & 6.0 \\
\hline Maintenance & Minutes per 1001 milk & 3.9 & 2.5 \\
\hline Grassland and forage production & Minutes per $1001 \mathrm{milk}$ & 3.0 & $5.2 * *$ \\
\hline
\end{tabular}

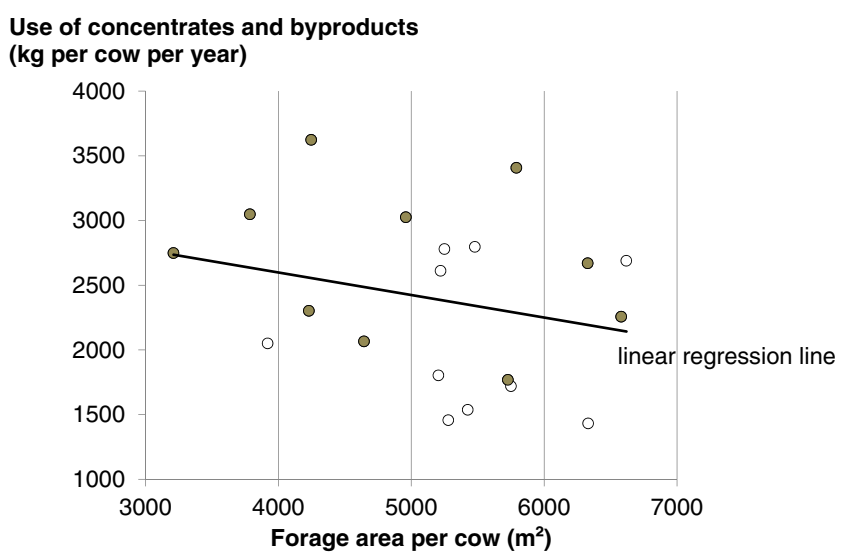

Fig. 3 Use of concentrates and byproducts related to available forage area per cow of zero-grazing (grey dots) and grazing (white dots) dairy farms

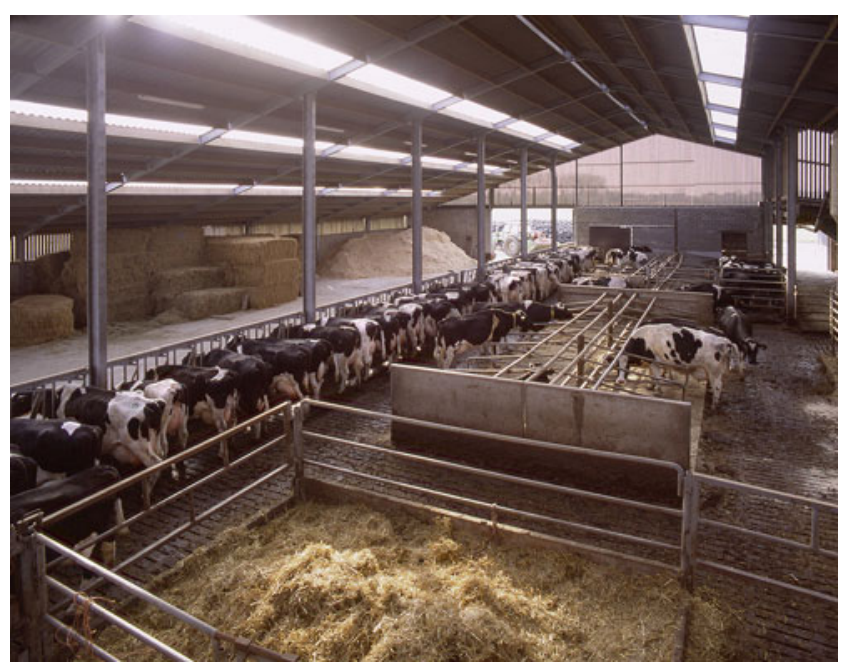

Fig. 4 Zero-grazing dairy systems in Flanders 


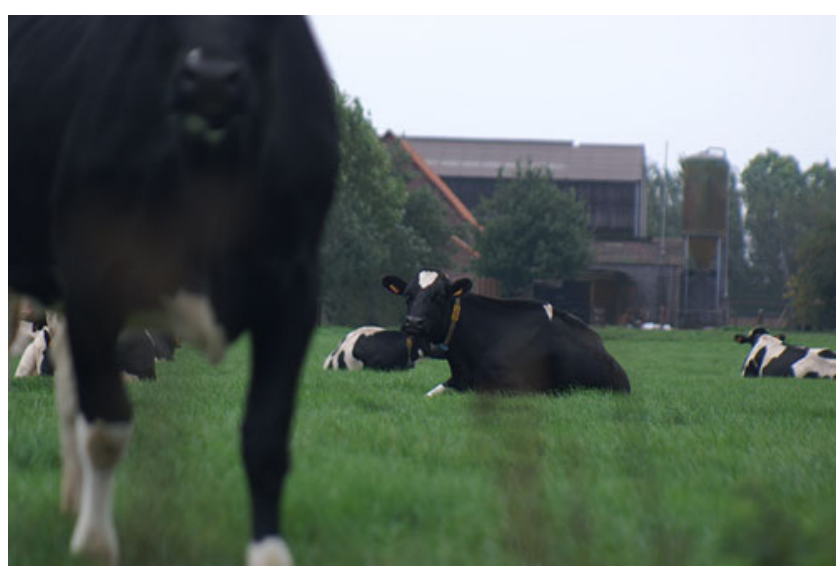

Fig. 5 Intensive grazing

into a higher economic performance, due to the lower milk price and higher variable costs at the zero-grazing farms.

For both groups, animal welfare was higher during the grazing period. On the grazing farms, the percentage of lame cows and cows with lesions during the summer was negatively correlated $\left(R^{2}=0.63\right)$ with the duration of the grazing period. This shows that longer grazing periods are associated with less lameness and fewer leg injuries, which may confirm the positive effect of grazing on cow welfare, as reported in several studies (von Keyserlingk et al. 2009). During winter, however, mean animal welfare was higher for the zero-grazing group. Since the quality of housing and cow management affects cow welfare (Bowell et al. 2003) and because dairy cows in our case study were housed during most of the year, zero-grazing farms may have met cow requirements better than grazing farms. For example, the mean barn space per cow and time spent on hoof care was significantly higher on the zero-grazing farms than on grazing farms, 8.3 versus $6.3 \mathrm{~m}^{2}$ of barn space per cow and 73 versus 36 min per cow on hoof care, respectively. It should be noted, however, that most farmers applied a shorter grazing period in 2010 than in previous years due to exceptionally dry and warm weather. Given the correlation between the duration of the grazing period and animal welfare indicators, the difference in animal welfare between grazing and zero-grazing farms could have been higher with longer grazing periods.

Through our approach, we addressed the suggestions made by De Mey et al. (2011) to improve social learning among farmers and farm advisors associated with the MOTIFS application and hence provide a more sound support for farm management. We combined a detailed analysis of the sustainability indicator values, underlying determining factors and related farm characteristics with an intensive interaction between researchers and farm advisors. This allowed us to focus on the essential farm management aspects with the highest potential to increase farm sustainability and to provide a better translation of the indicator results into practical advice.
We consider the formulation of detailed advice for farmers an essential additional step to the sustainability evaluation since sustainable agriculture requires integrated complex knowledge, which is often case-specific and needs to be developed in situ through close interaction among stakeholders. Rather than research or markets, this stakeholder interaction is increasingly being recognized as the trigger for innovation or change towards higher sustainability (Röling 2009).

\section{Conclusions}

We compared the integrated sustainability performance of intensive grazing versus zero-grazing dairy systems in Flanders (Figs. 4 and 5). Results showed that the zero-grazing farms in our case-study performed worse from an ecological and economic point of view compared with the grazing farms, while labor efficiency and animal welfare were not significantly different. The mean integrated sustainability score was higher for the intensive grazing systems, which indicates that a further shift from intensive grazing to zero-grazing could move dairy farming in Flanders further away from sustainability.

The use of concentrates and byproducts had a major influence on the economic and ecological performance of the farms. Hence, important management advice for zero-grazing farms is to optimize cows' rations to include more forages, optimize forage production and use, and avoid losses during harvesting, preservation, and feeding. During the discussion meeting with farmers, farm advisors, and an expert in ration optimization and forage production, site- and case specific advice for farmers of both groups was formulated.

Through our methodology, evaluation of the sustainability performance was supplemented with the formulation of useful advice for farmers of both groups. This translation of sustainability monitoring results into practical measures is an integral part of the application of MOTIFS, and we consider this an essential step to make progress towards higher sustainability.

\section{References}

Arsenault N, Tyedmers P, Fredeen A (2009) Comparing the environmental impacts of pasture-based and confinement-based dairy systems in Nova Scotia (Canada) using life cycle assessment. Int J Agric Sustain 7:19-41

Bockstaller C, Guichard L, Makowski D, Aveline A, Girardin P, Plantureux S (2008) Agri-environmental indicators to assess cropping and farming systems. A review. Agron Sustain Dev 28:139-149

Bowell VA, Rennie LJ, Tierney G, Lawrence AB, Haskell MJ (2003) Relationships between building design, management system and dairy cow welfare. Anim Welf 12:547-552 
Coléno FC, Duru M (1999) A model to find and test decision rules for turnout date and grazing area allocation for a dairy cow system in spring. Agric Syst 61:151-164

Conner DS, Campbell-Arvai V (2009) Consumer demand for pastureraised dairy products: results from Michigan. J Soil Water Conserv 64:175-178

De Mey K, D'Haene K, Marchand F, Meul M, Lauwers L (2011) Learning through stakeholder involvement in the implementation of MOTIFS, an integrated assessment model for sustainable farming in Flanders. Int J Agric Sustain 9:350-363

Haas G, Wetterich F, Köpke U (2001) Comparing intensive, intensive and organic grassland farming in southern Germany by process life cycle assessment. Agric Ecosyst Environ 83:43-53

Haskell MJ, Rennie LJ, Bowell VA, Bell MJ, Lawrence AB (2006) Housing system, milk production, and zero-grazing effects on lameness and leg injury in dairy cows. J Dairy Sci 89:42594266

Hernandez-Mendo O, von Keyserlingk MAG, Veira DM, Weary DM (2007) Effects of pasture on lameness in dairy cows. J Dairy Sci 90:1209-1214

Jenkins TC, McGuire MA (2006) Major advances in nutrition: impact on milk composition. J Dairy Sci 89:1302-1310

Kristensen T, Soegaard K, Kristensen IS (2005) Management of grasslands in intensive dairy livestock farming. Livest Prod Sci 96:6173

Metera E, Sakowski T, Sloniewski K, Romanowicz B (2010) Grazing as a tool to maintain biodiversity of grassland - a review. Anim Sci Paper Rep 28:315-334

Meul M, Nevens F, Reheul D, Hofman G (2007) Energy use efficiency of specialised dairy, arable and pig farms in Flanders. Agric Ecosyst Environ 119:135-144

Meul M, Van Passel S, Nevens F, Dessein J, Rogge E, Mulier A, Van Hauwermeiren A (2008) MOTIFS: a monitoring tool for integrated farm sustainability. Agron Sustain Dev 28:321-332

Meul M, Nevens F, Reheul D (2009) Validating sustainability indicators: focus on ecological aspects of Flemish dairy farms. Ecol Indic 9:284-295

Nevens F, Verbruggen I, Reheul D, Hofman G (2006) Farm gate nitrogen surpluses and nitrogen use efficiency of specialized dairy farms in Flanders: evolution and future goals. Agric Syst 88:142-155

Olmos G, Boyle L, Hanlon A, Patton J, Murphy JJ, Mee JF (2009) Hoof disorders, locomotion ability and lying times of cubicle-housed compared to pasture-based dairy cows. Livest Sci 125:199-207
Parsons RL, Luloff AE, Hanson GD (2004) Can we identify key characteristics associated with grazing-management dairy systems from survey data? J Dairy Sci 87:2748-2760

Platteau J, Van Gijseghem D, Van Bogaert T (eds) (2010) Landbouwrapport 2010. Departement Landbouw en Visserij, Brussel

Roelofs PFMM, Vogelzang TA, Kroeze GH, Schotanus L (2005) Verbetering arbeidsefficiëntie op vier melkveebedrijven. Agrotechnology \& Food Innovations, Wageningen UR

Röling N (2009) Pathways for impact: scientists' different perspectives on agricultural innovation. Int J Agric Sustain 7:83-94

Rotz CA, Taube F, Russelle MP, Oenema J, Sanderson MA, Wachendorf M (2005) Whole-farm perspectives of nutrient flows in grassland agriculture. Crop Sci 45:2139-2159

Schellekens A, Van de Ven G, De Campeneere S, De Caesteker E, Ryckaert I, Rombouts G (2008) Bewust beperkt beweiden: Beter voor koe en boer? Brochure Voedergewassen 2008-Oogstjaar 2007. Landbouwcentrum voor Voedergewassen, pp 87-92

Sobry L, Goossens X, Opsomer G, Nevens F, De Smet S, Ödberg F, Maes D, Lommelen F, Tuyttens F, Geers R (2005) Hoe wel zijn mijn koeien? Evaluatie van dierenwelzijn en-gezondheid op melkveebedrijven. Steunpunt Duurzame Landbouw, Gontrode

Soriano FD, Polan CE, Miller CN (2001) Supplementing pasture to lactating Holsteins fed a total mixed ration diet. J Dairy Sci 84:2460-2468

Spörndly E, Wredle E (2004) Automatic milking and grazing - effects of distance to pasture and level of supplements on milk yield and cow behavior. J Dairy Sci 87:1702-1712

Thomassen MA, van Calker KJ, Smits MCJ, Iepema GL, de Boer IJM (2008) Life cycle assessment of conventional and organic milk production in The Netherlands. Agric Syst 96:95-107

Van Passel S, Meul M (2012) Multilevel and multi-user sustainability assessment of farming systems. Environ Impact Assess Rev 32:170 180

Van Vuuren AM, Van Den Pol-Van Dasselaar A (2006) Grazing systems and feed supplementation. In: Elgersma A, Dijkstra J, Tamminga S (eds) Fresh herbage for dairy cattle. Springer, pp 85-101

von Keyserlingk MAG, Rushen J, de Passillé AM, Weary DM (2009) The welfare of dairy cattle - key concepts and the role of science. J Dairy Sci 92:4101-4111

Whitehead DC (1995) Grassland nitrogen. CAB International, Wallingford

Zimmermann A (2008) Optimization of sustainable dairy-cow feeding systems with an economic-ecological LP farm model using various optimization processes. J Sustain Agric 32:77-94 